\title{
Editorial: Special Issue on the Impact of Business Ethics on Public Life
}

\author{
Patrick Flanagan $^{1} \cdot$ Marilynn Fleckenstein $^{2} \cdot$ Linda Sama $^{3} \cdot$ Victoria Shoaf $^{4}$
}

Received: 26 April 2017/ Accepted: 19 May 2017/Published online: 26 May 2017

(C) Springer Science+Business Media Dordrecht 2017

"The Impact of Business Ethics on Public Life" was the theme of the 21st Annual International Vincentian Conference Promoting Business Ethics organized by DePaul University (Chicago, IL), Niagara University (Niagara, NY), and St. John's University (New York, NY), the three American universities sponsored by the Congregation of the Mission (the Vincentian Community of Catholic religious priests and brothers). Vincentian universities draw their mission from the life of Saint Vincent DePaul, a seventeenth-century saint of the Roman Catholic Church. DePaul spent his life seeking solutions to resolve the economic hardship that faced his country of France during his time. It seems appropriate that a Vincentian conference should speak about business ethics, for during DePaul's life he sought religiously to make ensure financial integrity and fiscal sustainability. DePaul interacted as comfortably with the abandoned poor as he was with the royalty and the rich. For DePaul, it was all about education and making the connections. In one sense, even then, as small as DePaul's world was, he was pushing the boundary, exploring the

Patrick Flanagan

flanagap@stjohns.edu

1 Department of Theology and Religious Studies, St. John's College of Liberal Arts and Sciences, St. John's University, 8000 Utopia Parkway, Jamaica, NY 11439, USA

2 Department of Philosophy, Niagara University, Alumni Hall, Lewiston, NY 14109, USA

3 Department of Management, The Peter J. Tobin College of Business, St. John's University, 8000 Utopia Parkway, Jamaica, NY 11439, USA

4 Department of Accounting, The Peter J. Tobin College of Business, St. John's University, 8000 Utopia Parkway, Jamaica, NY 11439, USA frontier, and creating systems for all people to flourish in this "new world."

For the first time in its history, the Conference was held at All Hallows College in Dublin, Ireland. All Hallows was one of three international Vincentian institutions colleges outside America. The other two are Adamson in Manila, Philippines, and DePaul College in Mysore, India. Subsequent to this Conference, unfortunately, All Hallows wound down its operations and was purchased by Dublin City University. Since 1842, All Hallows had educated a goodly number of men for ministerial priesthood in the global village and eventually, as vocations declined in Ireland, evolved into a full-service college granting undergraduate and graduate degrees. The sad demise of All Hallows as well as other private institutions can serve as an object of research for business ethics.

Dublin provided the perfect venue to discuss this burgeoning topic. This capital city, the largest in Ireland, has seen extraordinary financial growth in its history most notable the Celtic Tiger as well as the pressing fiscal challenges of an economy that followed. Given its geographic location, conversations occurred here at this Conference among people from all different sectors of the world. These exchanges, always gracious and prudent-a hallmark of this conference-provoked, challenged, and encouraged educators and practitioners to think and act mindfully in an ever-changing socioeconomic political environment.

All of the professors and corporate leaders that who presented at this conference offered solid reflections on the impact of business ethics on public life. The papers presented in this volume of a Special Edition of the Journal of Business Ethics represent the best of the rich array of the concurrent paper sessions, panel discussions, and keynote presentations. The authors push beyond parochial borders, 
recognizing that the forum for economics is now global. The issues they concern themselves with run the gamut of fiscal concern. Drs. James Delaney and David Martin's (2016) paper, "Therapy, Enhancement, and Medicine: Challenges for the Doctor-Patient Relationship and Patient Safety," was awarded the Primeaux Prize for the best paper, named in honor of Rev. Dr. Patrick Primeaux, S.M., one of the early organizers of this conference.

Throughout the three days, participants and presenters at this conference engaged in lively conversation about the increasing responsibility of leaders to address current ethical challenges in management decision-making. Keynote speakers, concurrent sessions, panels, and poster presentations examined critical concerns related to this topic. Some questioned whether or not there is a growing deficit in ethical leadership. That is, do our leaders and corporations, take responsibility for social and political institutions that truly reflect society? What lessons can we learn from the economic, political, and social crises of our times? Are business ethics, public virtue, and social mores intrinsically linked? What are the consequences of free enterprise and globalization for social justice? The articles herein offer a wide range of perspectives on these pressing questions.

Frecknall-Hughes et al. (2016) examine ethical influences on the work of tax practitioners. Using the Defining Issues Test in an innovative way, these scholars examine how a consequentialist approach takes precedent over a deontological one. Thomson and Jones (2016) extend the growing body of literature in postcolonial theory by studying global migration and its impact on professional insecurity and moral agency. Their work investigates how those with diverse social identities face significant challenges that others do not and what import this has on the accounting profession and society in Canada. Kinsella (2016) argues that "the dynamics of hostile takeovers" are a "form of corporate warfare." Kinsella (2016) defers to the just war theory as archetype to which such takeovers might be ethically evaluated. Culiberg and Mihelič (2016) offer us a review of literature on whistle-blowing in an effort to update us and demonstrate the role of such a behavior in business ethics. They emphasize "the wheel of whistle-blowing" to advance critical thought on this topic. Schoen (2016) offers us an ethical analysis of 2007-2009 financial crisis. He does so by examining four critical areas that served as the legs of this economic downturn.

Delaney and Martin (2016) extend business ethics to the medical field by discussing the challenges to the traditional doctor-patient relationship in this era of therapy and enhancement medicine. They believe that "straightforward business practices" can offer a "reasonable alternative" by which a more honest and healthy dynamic can exist between doctors and patients. Kearns (2016) defers to the import of Roman Catholic social teaching namely Pope Benedict XVI's 2009 Caritas in Veritate to discuss corporate social responsibility (CSR) in Ireland. Using the encyclical's "normative framework of three logics," Kearns (2016) critically evaluates the Irish CSR plan. Senander (2016) uses the Catholic church not a source of scholarship, but of research in addressing the maelstrom of abuse that has plagued the Catholic church. Using a method not unlike Kinsella (2016), Senander (2016) proposes the "appropriation of codes of conduct and cultural practices from the corporate world" to ecclesial leadership for a more ethical environment. Chun (2016) moves beyond Aristotle and Alasdair MacIntyre's works to examine organizational virtue from a wide variety of stakeholders and to link "virtues and organizational outcomes." Chun (2016) undertakes a large-scale empirical study that will prove useful to companies in how their perception by stakeholders in the marketplace might be enhanced.

The Vincentian universities in the USA-DePaul University, Niagara University, and St. John's University-have sponsored a special issue of the Journal of Business Ethics every year for over twenty years, selected from the best papers presented at the International Vincentian Conference Promoting Business Ethics. The carefully chosen works presented here, from global scholars and collaborations, offer a linkage between theory and practice that addresses modern managerial ethical concerns and applications. This special issue makes a relevant and substantive contribution to the important issue of the impact of business ethics on public life.

\section{References}

Chun, R. (2016). Organizational virtue and performance: An empirical study of customers and employees. Journal of Business Ethics. doi:10.1007/s10551-016-3262-z.

Culiberg, B., \& Mihelič, K. K. (2016). The evolution of whistleblowing studies: A critical review and research agenda. Journal of Business Ethics. doi:10.1007/s10551-016-3237-0.

Delaney, J. J., \& Martin, D. (2016). Therapy, enhancement, and medicine: Challenges for the doctor-patient relationship and patient safety. Journal of Business Ethics. doi:10.1007/s10551016-3042-9.

Frecknall-Hughes, J., Moizer, P., Doyle, E., \& Summers, B. (2016). An examination of ethical influences on the work of tax practitioners. Journal of Business Ethics. doi:10.1007/s10551016-3037-6.

Kearns, A. J. (2016). Rebuilding trust: Ireland's CSR plan in the Light of Caritas in Veritate. Journal of Business Ethics. doi:10.1007/ s10551-016-3238-z.

Kinsella, M. (2016). Hostile takeovers-An analysis through just war theory. Journal of Business Ethics. doi:10.1007/s10551-0163256-x. 
Schoen, E. J. (2016). The 2007-2009 financial crisis: An erosion of ethics-A case study. Journal of Business Ethics. doi:10.1007/ s10551-016-3052-7.

Senander, A. (2016). Beyond scandal: Creating a culture of accountability in the Catholic Church. Journal of Business Ethics. doi:10.1007/s10551-016-3217-4.
Thomson, K., \& Jones, J. (2016). Precarious professionals: (in)Secure identities and moral agency in neocolonial context. Journal of Business Ethics. doi:10.1007/s10551-016-3218-3. 